\title{
Content Creation Date
}

National Cancer Institute

\section{Source}

National Cancer Institute. Content Creation Date. NCI Thesaurus. Code C69199.

The date on which data creation began. 